\title{
On the Comparative Impact of Self-assessment and Teacher- assessment on Iranian EFL Learners' Academic Motivation
}

\author{
Asghar Salimi (Corresponding author) \\ Department of English, University of Maragheh, Maragheh, Iran \\ E-mail: AsgharSalimi356@gmail.com \\ Vahid Nowrozi Larsari \\ Department of Teaching English Language, Sarab Branch, Islamic Azad University, Sarab, Iran \\ E-mail: v.nowrozi@gmail.com
}

Doi:10.7575/aiac.alls.v.6n.6p.74

URL: http://dx.doi.org/10.7575/aiac.alls.v.6n.6p.74
Received: $18 / 06 / 2015$

Accepted: 02/09/2015

\begin{abstract}
Nowadays, the function of language teaching and testing has been paid much attention by researchers. There is an overall notion in the literature that motivation, as driving force, is one of the likely learners' traits. The aim of this study was to examine the comparative impact of self-assessment and teacher-assessment on learners' academic motivation. The participants were 60 intermediate students in two groups at Novin-Rezvan Foreign institute. At the beginning of semester, the instructor gave a motivation questionnaire as pre-test to the students, and then both groups were put to the similar content and instructional method for reading strategies. There was only one difference, i.e., the students in the experimental group self-assessed themselves, whereas the students in another group were assessed by the teacherassessment. At the end of treatment session, a post-motivation questionnaire was given to the students to assess level of their motivation. Two t-tests were run, and the results showed that self-assessment play an important impact on Iranian EFL learners' academic motivation.
\end{abstract}

Keywords: Motivation, Self-assessment, Teacher-assessment, Assessment

\section{Introduction}

It is generally claimed that it is indispensable to evaluate the learners' performance by the use of a diversity of assessment strategies. Actually, assessment is considered as a fundamental element for language teaching and testing, allowing them to monitor their needs and focus on student's views of development (Harris, 1997). Yet, in traditional classrooms, are dominant in Iran, the teacher is the only evaluator (as cited in Birjandi \& Tamjid, 2010). Such assessment is acceptable in terms of tests whose items have one correct answer, but in performance tests, such as reading tests, the evaluation is not so straight-forward (Birjandi \& Tamjid, 2010). Alternative assessment including selfassessment, learners are trained to assess their own learning progress, and can recognize their own strengths and weakness so as to compensate for the restrictions of teacher-assessment (Noonan, 2000). Besides, motivation is regarded as a basic role in the achievement of language learning and teaching (Nakanishi, 2002). Dörnyei (2000) also contends that motivation offers the main incentive to engage in learning among learners. Hence, the aim of the present study is to see if self-assessment and teacher-assessment have an important impact on academic motivation learners' motivation.

\subsection{Research Question}

Q1: Is there any statistically significant difference between the impact of self-assessment and teacher-assessment on Iranian EFL learners' academic motivation?

1.2 Hypotheses

H01: There is no statistically significant difference between the impact of self-assessment and teacher-assessment on Iranian EFL learners' academic motivation.

\section{Review of the Related Literature}

2.1 Assessment

According to Wang and Wang (2007), the word "assessment" originates from 'ad sedere' - means to sit down beside (as cited in Birjandi \& Tamjid, 2010). They also discussed that the etymology of assessment is mainly based on the learner guidance and feedback. Many methodologists such as Erwin (1991) stated assessment as "the process of defining, analyzing, understanding, and using information to upsurge students' learning and development” (p.14). Angelo (1995) defines: "assessment is an ongoing process aimed at understanding and improving student learning. It involves making our expectations explicit and public; setting appropriate criteria and high standards for learning quality; systematically gathering, analyzing and interpreting evidence to determine how well performance matches those expectations and standards" (p.7). Richards and Schmidt (2002) believes that assessment is a methodical method 
to assemble material and make implications and conclusions about pupils' performance. In addition, Airasian (1994) defined assessment as gathering, separating and explaining information to make to make decisions on student performance. He also states that "in classroom, assessment can be done conducted to diagnose student problems, to judge their academic performance, to provide feedback to student and to plan instruction" (p.16).

\subsection{Self-assessment}

According to Naeini (2011), self-assessment has obtained significant consideration in recent years to put emphasis on evaluate of students' language capabilities. Also, self-assessment relates to checking learners' performance on a language learning task after completing or monitoring their success in using a language (Richards \& Schmidt, 2002). They also believed that self- assessment is an example of a meta-cognitive strategy in second language learning. According to Mousavi (1995), self-assessment is the learners' own assessment of their language ability, in terms of their capability to use the language in various contexts. In this regard, Harris (1997) maintained that self-assessment plays as an important role in language learning, helps the learner to increase independency which the learner can monitor his/her progress his/her individual needs. Liang (2006) defined the term "self-assessment" as follows:

* Self-assessment plays as a central role in a learner-based curriculum.

* Self-assessment is different from teacher-assessment for different evaluation purposes.

* Self-assessment is an ability to evaluate learning progress and learning effectiveness.

\subsection{Advantages of self-assessment}

According to researchers such as Coombe \& Canning (2002) have discussed the application and advantages of selfassessment as follows:

* Enhancing and improving learning and teaching.

* Raising learners' awareness of their own learning and teaching.

* Developing learner's autonomy.

* Reducing the burden of assessment placed on teachers.

* Developing range of evaluation into effective contexts.

Harris (1997) also believes that one of the main reasons for introducing self-assessment, that is, self-assessment is a key learning strategy for autonomous language learning, which enables the students to monitor their progress and relate learning to individual needs. In this regard, Dickson (1987) suggests three main points for applying self-assessment in language learning and teaching. First, Self-assessment leads toward evaluation, which is as a basic educational objective in its own place. Secondly, Self-assessment also plays an important role in self-determination. Thirdly, Self-assessment is one way of declining the assessment burden on the teacher.

\section{Methodology}

\subsection{Participants}

The participants of this study were EFL learners from Novin-Rezvan foreign languages institute in Rasht with the range of 17 to 25 years old. There were 90 learners in intermediate level who were given PET as the homogenization test. Those participants whose scores fell between one standard deviation above and below the mean were selected and they were defined as intermediate EFL learners in this study. Then, the researcher divided them into two groups randomly. Each group consisted of an equal number of 30 participants. One experimental group treated with self-assessment and the other one with teacher-assessment. For evaluating the writing and speaking part of the PET, there was another rater who helped the researcher to rate the paper. Prior to the actual administration, the tests were piloted among 30 students with the same language proficiency level and almost the same characteristics of the 90 students who took the test later.

\subsection{Instrumentation}

\subsubsection{Gardner's Attitude/Motivation}

It is prepared by Gardner (2004) to assess the subjects' degree of motivation. It includes 25 items and in front of each item six alternatives including "Strongly disagree", "Moderately disagree", "Slightly disagree", "Slightly agree", "Moderately agree", and "Strongly agree". The scoring procedure of the questionnaire was from one to six Likert scale. The participants were instructed to answer each item by putting an underline/circle around these alternatives as quickly as possible. It is necessary to note that reliability of this questionnaire was assessed by using Cronbach's Alpha Coefficient. If it is greater than 0.7, a scale is considered reliable. Hence, Cronbach's Alpha Coefficient for this measurement is 0.76 indicate that it has sufficiently coefficient alpha scores.

\subsubsection{The Preliminary English Test (PET)}

In order to homogenize the participants, the researcher used PET test (Appendix A). The sample of the test which was used in this study included three sections of reading (five parts), writing (three parts), and listening (four parts). The reading section of this language proficiency test had 35 items including five three-option multiple-choice items, five matching, 10 true/false, and 15 four-option multiple choice items. For the writing section, there were three parts including five sentence transformation items in the first part and in the other two parts, students were required to write one essay for each part; in other words, in the second part students were required to write a short communicative message about 35-45 words, and for the third part, they were required to write a longer piece of continuous writing 
about 100 words. The allotted time for the PET reading and writing parts was one hour and 30 minutes. In the listening section, students were required to answer 13 three-option multiple-choice items and six filling-the-gap items and six true/false items. The allotted time for the PET listening part was 30 minutes. It is necessary to mention that with the aim of saving time, the researcher used only reading, writing, and listening parts of the PET. To conduct the speaking part of the PET, a qualified examiner was required and since such qualified examiner was professionally not allowed to engage in any application of the PET and all Cambridge ESOL exams, for that matter, without the direct supervision of Cambridge, it was thus not possible for the researcher to run the speaking part of the test in its genuine manner. Moreover, the main focus of the study was reading comprehension, thus the speaking section was not administered in this study. Therefore, as a whole, this test had 65 closed-ended items and two open-ended writing tasks; each section valued 25 marks, adding up to 75 marks on the whole. Before the main administration, the test was piloted with 30 students at intermediate level with the same characteristics of the target sample. Item analysis and reliability estimates were carried out after the pilot administration and three items out of the 65 total items were found to be malfunctioning and were excluded. The allotted time for answering the remaining 62 items and the two tasks was two hours.

\subsection{Procedure}

To achieve the purpose of this study, the following steps were taken:

At the beginning of the study, 90 learners of intermediate level at Novin-Rezvan Foreign languages institute were selected through non-random selection. Then, PET already piloted among 30 subjects with similar characteristics was administered to homogenize the participants regarding their overall language proficiency. Next 60 participants, whose scores fell between one standard deviation above and below the mean, were selected. Then, they were randomly divided into two groups and two classes so that every member had an equal chance to be located to each group. In the next step, the participants were asked to fill in Attitude/Motivation Test Battery (AMTB) questionnaire to measure their motivation. In fact, the researcher gave a pre-motivation questionnaire to the students before teaching the reading strategies. From the second session on, the regular class teaching syllabus contained teaching and practicing section one of the reading strategies for five sessions. After that these two groups were taught the same strategies and then a reading comprehension test was administrated. For self-assessment group (experimental group), the students were assessed by the students themselves, while the students of the control group received instruction on the same reading strategies and practice those strategies, but there was no self-assessment given to them. Instead, traditional teacher-assessment was used to assess them. After the end of treatment session, the researcher required the participants fill out the Attitude/Motivation Test Battery (AMTB) questionnaire again to measure their motivation after applying the treatments. Finally, obtained data was analyzed to test the proposed null hypothesis of the study. The results of the posttest showed whether using self-assessment and teacher-assessment instruction has any significant impact on the learners' motivation.

\section{Results and Discussions}

In order to fulfill the purpose of this study which was to compare the impact of self-assessment and teacher-assessment on Iranian EFL learners' academic motivation, the researcher asserted the following question and hypothesis:

$\mathbf{Q}_{1}$ : Is there any significance difference between the impact of self-assessment and teacher-assessment on Iranian EFL learners' academic motivation?

$\mathbf{H}_{\mathbf{0}}$ : There is no significant difference between the impact of self-assessment and teacher-assessment on Iranian EFL learners' academic motivation.

The researcher conducted a series of calculation and statistical routines in order to test the hypothesis and come up with certain results which are explained.

The above research question sought to find out whether self-assessment and teacher-assessment has any strong impact on Iranian EFL learners' academic motivation or not. The scores in the questionnaire were analyzed. The particular analysis used was paired sample T-test. Within both experimental and control groups.

Table 4.1 Descriptive statistics for experimental and control Group

\begin{tabular}{clrccc}
\hline & Group & $\mathrm{N}$ & \multicolumn{1}{c}{ Mean } & Std. Deviation & Std. Error Mean \\
\hline Pre & Experimental Group & 30 & 5.0760 & .39484 & .07209 \\
& Control Group & 30 & 5.0773 & .55310 & .10098 \\
Post & Experimental Group & 30 & 5.0773 & .55310 & .10098 \\
& Control Group & 30 & 5.1747 & .30643 & .05595 \\
\hline
\end{tabular}

Table 4.1 shows the results of descriptive statistics for the two groups. Experimental group is the self-assessment and control group is related to the teacher-assessment. As it can be observed, the experimental group has $\mathrm{M}=5.0760$ and $\mathrm{SD}=.39$ in the pre-motivation questionnaire, and $\mathrm{M}=5.0773$ and $\mathrm{SD}=.55$ in the post-motivation questionnaire. Based on the obtained results, the difference between the scores of the pre and post-motivation tests in the experimental group or the self-assessment is insignificant. In addition, the results of the control group indicates $\mathrm{M}=5.0773$ and $\mathrm{SD}=.55$ in the pre-motivation questionnaire, and $\mathrm{M}=5.1747$ and $\mathrm{SD}=.30$ in the post-motivation questionnaire. 
4.2 Paired Samples Test for the experimental group

\begin{tabular}{|c|c|c|c|c|c|c|c|c|c|}
\hline & & \multicolumn{5}{|c|}{ Paired Differences } & \multirow[t]{3}{*}{$\mathrm{t}$} & \multirow[t]{3}{*}{ df } & \multirow{3}{*}{$\begin{array}{l}\text { Sig. (2- } \\
\text { tailed) }\end{array}$} \\
\hline & & \multirow[t]{2}{*}{ Mean } & \multirow[t]{2}{*}{$\begin{array}{l}\text { Std. } \\
\text { Deviati } \\
\text { on }\end{array}$} & \multirow[t]{2}{*}{$\begin{array}{l}\text { Std. } \\
\text { Error } \\
\text { Mean }\end{array}$} & \multicolumn{2}{|c|}{$\begin{array}{l}95 \% \text { Confidence } \\
\text { Interval of the } \\
\text { Difference }\end{array}$} & & & \\
\hline & & & & & Lower & Upper & & & \\
\hline Pair 1 & $\begin{array}{l}\text { PRE - } \\
\text { POST }\end{array}$ & -.00133 & .64309 & .11741 & -.24147 & .23880 & -.011 & 29 & .045 \\
\hline
\end{tabular}

Table 4.2 contains the results of the paired sample test for the pre- and post-motivation tests in the experimental group or the self-assessment group. As it can be seen, the differences between the scores of the motivation questionnaires in the pre- and post-motivation in the experimental group are significant since the level of significance is .045 which is smaller than the threshold level 0.05 .

4.3 Paired Samples Test for the control group

\begin{tabular}{ccccccccc}
\hline & & \multicolumn{3}{c}{ Paired Differences } & t & df & Sig. (2- \\
tailed)
\end{tabular}

Based on the results of table 4.3, the paired sample test is utilized for the control group or the teacher-assessment group. A close look at the table indicated that the significance level is $.44>0.05$, indicating that there are not statistically significant differences between the scores of the pre- and post-motivation tests.

4.4 Independent Samples Test experimental and control group

\begin{tabular}{|c|c|c|c|c|c|c|c|c|c|c|}
\hline & & \multirow{2}{*}{\multicolumn{2}{|c|}{$\begin{array}{c}\text { Levene's Test for } \\
\text { Equality of Variances }\end{array}$}} & \multicolumn{7}{|c|}{ t-test for Equality of Means } \\
\hline & & & & \multirow{5}{*}{$\mathrm{t}$} & \multirow{5}{*}{$\mathrm{df}$} & \multirow{5}{*}{$\begin{array}{l}\text { Sig. (2- } \\
\text { tailed) }\end{array}$} & \multirow{5}{*}{$\begin{array}{c}\text { Mean } \\
\text { Difference }\end{array}$} & & & \\
\hline & & \multirow[t]{4}{*}{$\mathrm{F}$} & \multirow[t]{4}{*}{ Sig. } & & & & & \multirow{4}{*}{$\begin{array}{l}\text { Std. Error } \\
\text { Difference }\end{array}$} & \multirow{3}{*}{\multicolumn{2}{|c|}{$\begin{array}{c}95 \% \text { Confidence } \\
\text { Interval of the } \\
\text { Difference }\end{array}$}} \\
\hline & & & & & & & & & & \\
\hline & & & & & & & & & & \\
\hline & & & & & & & & & Lower & Upper \\
\hline$\underline{P}$ & Equal variances & 4.341 & .042 & -.011 & 58 & .991 & -.00133 & .12407 & -.24969 & .24703 \\
\hline$\underline{\mathrm{R}}$ & assumed & & & & & & & & & \\
\hline$\underline{E}$ & Equal variances & & & -.011 & 52.464 & .991 & -.00133 & .12407 & -.25025 & .24759 \\
\hline & not assumed & & & & & & & & & \\
\hline
\end{tabular}

Table 4.4 shows the independent sample test of both experimental and control groups for the pre-test. The equal variance assumption was examined to conduct the independent sample test. To this end, the Leven's test for equality of variances was used in order to investigate the equal variance assumption. The obtained results indicated that the level of significance of the Leven's test (.04) is lower than .05, suggesting that the equal variance assumption is not supported. Hence, the second row of data is examined regarding the mean score of the t-test. In addition, the results indicated that the level of significance of the t-test (-.011) for the equality of means is .99 that is higher than the level of significance .05 , indicating that the differences between the mean scores of both experimental and control groups in the pre-test are not statistically significant.

\subsection{Post-test Results}

The researcher administrated the motivation post-test to both experimental and control groups once the treatment period was over for each of them.

\subsection{Post-Test Descriptive Statistics}

To test the null hypothesis which stated there is no significant difference between the effects of self-assessment and teacher-assessment on the EFL learners' motivation, an independent samples $t$-test had to be run to compare the mean scores of both groups. The descriptive statistics of the motivation post-test of both groups are shown in Table 4.5. 
Table 4.5 Descriptive Statistics of the motivation Post-test

\begin{tabular}{|c|c|c|c|c|c|c|c|}
\hline & group & & $\mathrm{N}$ & Mean & Std. Deviation & $\begin{array}{l}\text { Std. } \\
\text { Mean }\end{array}$ & Error \\
\hline \multirow[t]{2}{*}{ POST } & $\begin{array}{l}\text { experiment= } \\
\text { assessment }\end{array}$ & self- & 30 & 5.2117 & .49134 & .08971 & \\
\hline & $\begin{array}{l}\text { control= } \\
\text { assessment }\end{array}$ & teacher- & 30 & 5.1747 & .30643 & .05595 & \\
\hline
\end{tabular}

As Table 4.5 shown, the teacher-assessment group turned out to obtain a lower mean, namely 5.1747 , than the selfassessment group who obtained a mean of 5.2117. Moreover, the skewness ratio obtained by both groups fell within the acceptable range of \pm 1.96 , which revealed normality for both distributions. Therefore, the first assumption for running an independent-samples $t$-test in order to compare the mean scores of the two experimental groups was observed and as a result, running as independent-samples $t$-test was legitimate.

\subsection{Testing the Null Hypothesis}

To verify the null hypothesis of the study that stated "there is no significant difference between the impact of selfassessment and teacher-assessment on Iranian EFL learner's academic motivation, the researcher conducted an independent sample t-test. Table 4.8 shows the independent samples t-test results on the two groups on the motivation post-test.

Table 4.6 Independent Samples Test for experimental and control group

\begin{tabular}{|c|c|c|c|c|c|c|c|c|c|c|}
\hline & & \multicolumn{2}{|c|}{$\begin{array}{l}\text { Levene's Test } \\
\text { for Equality of } \\
\text { Variances }\end{array}$} & \multicolumn{7}{|c|}{ t-test for Equality of Means } \\
\hline & & \multirow[t]{2}{*}{$\mathrm{F}$} & \multirow[t]{2}{*}{ Sig. } & \multirow[t]{2}{*}{$\mathrm{t}$} & \multirow[t]{2}{*}{ df } & \multirow[t]{2}{*}{$\begin{array}{l}\text { Sig. (2- } \\
\text { tailed) }\end{array}$} & \multirow[t]{2}{*}{$\begin{array}{c}\text { Mean } \\
\text { Difference }\end{array}$} & \multirow[t]{2}{*}{$\begin{array}{l}\text { Std. Error } \\
\text { Difference }\end{array}$} & \multicolumn{2}{|c|}{$\begin{array}{l}\text { 95\% Confidence } \\
\text { Interval of the } \\
\text { Difference }\end{array}$} \\
\hline & & & & & & & & & Lower & Upper \\
\hline $\begin{array}{l}\mathrm{P} \\
\mathrm{O} \\
\mathrm{S}\end{array}$ & $\begin{array}{l}\text { Equal } \\
\text { variances } \\
\text { assumed }\end{array}$ & 7.763 & .007 & .350 & 58 & .0034 & .03700 & .10572 & -.17463 & .24863 \\
\hline $\mathrm{T}$ & $\begin{array}{l}\text { Equal } \\
\text { variances not } \\
\text { assumed }\end{array}$ & & & .350 & 48.595 & .0034 & .03700 & .10572 & -.17550 & .24950 \\
\hline
\end{tabular}

Based on the obtained results of Table 4.6, the equal variance assumption is investigated to conduct the independent sample test of both groups for the post-test. At first, Levene's test for equality of variances is utilized to investigate the equal variance assumption. As it can be observed, the level of significance of the Levene's test (.00) is lower than the threshold 0.05 , highlighting that the equal variance assumption is not supported. Therefore, the second row of data is investigated concerning the mean. The results indicate that the level of significance of the t-test is (.72) for equality of means. There are statistically significant differences between the mean scores of both groups in the post-test. Based on Table 4.7, as the mean score of the self-assessment group (5.2117) was higher than the mean score of the teacherassessment group (5.0773), it was found that self-assessment group had significantly more significant effect on the learners' motivation compared to teacher-assessment. In fact, self-assessment as alternative assessment had significantly more positive impact on the motivation of EFL learners compared to teacher-assessment. Therefore, selfassessment can provide a motivating and low tension and apprehension situation for second language learning. This finding is compatible with the findings of Birjandi and Tamjid (2010). Also, they made an attempt to investigate the role of self-assessment in promoting Iranian EFL Learners' motivation. They investigated the role of journal writing as a self-assessment teaching in promoting Iranian EFL learners' motivation. The subjects were 60 intermediate learners in two groups. The experimental group was treated with journal writing. At the beginning and end of the treatment session, both groups took test for their homogeneity, and filled out a questionnaires concerning motivation. The findings showed that writing journals play a role in developing the learners' motivation.

\section{Conclusion and Implication}

The present study has provided empirical evidence on the comparative study of the effectiveness of self-assessment and teacher-assessment on learners' academic motivation. With respect to the obtained findings, the researcher came to a certain conclusion that self-assessment has an important impact on learners' academic motivation. Also, the researcher provided some pedagogical implications so as to increase the place of self-assessment in Iranian education context. First of all, To begin with, it may hopefully increase students' and teachers' awareness of these powerful strategies (Birjandi \& Tamjid, 2010). In fact, since self-assessment is not common in Iranian educational systems, it is 
hoped that we should raise students' and teachers' awareness of self-assessment. Therefore, through the incorporation of self- assessment activities into everyday ELT instruction, students can gain a better comprehending of the expected learning outcomes, find their strengths and weaknesses, and set goals for future improvement (Birjandi \& Tamjid, 2010). Secondly, by creating a supportive environment in the assessment, the students can have a better understanding of the learning outcomes (Liang, 2006). For instance, extensive teacher feedback for modeling is an example of creating a supportive environment in the assessment (Liang, 2006). Thirdly, the teachers who aim at utilizing selfassessment in their classes should decide on "clear criteria to base their assessment on. Both teachers and students need to agree on clear criteria to use while assessing the students' performance" (Liang, 2006.p.1). In fact, He also mentioned that "well-defined scoring criteria and good descriptors lead to provide a close guidance in the assessment" (p.1). Fourth, the researchers believe that directed knowledge develop a sense of responsibility, so-called autonomy (Birjandi \& Tamjid, 2010). Fifth, it is recommending that teachers should cognizant of the motivation of the students, because, they can increase self-assessment easily in their classroom (Giang, 2008).

\section{References}

Angelo, T. A. (1995). Reassessing (and Defining) Assessment. The AAHE Bulletin, 48 (2), November 1995, pp. 7-9.

Airasian, P. W. (1994). Classroom assessment (2nd ed.). New York: McGraw Hill

Coombe , C. , \& Canning, C (2002) .Using Self-assessment in the classroom : Rationale and Suggested Techniques .Retrieved in September 7, 2010 from : http:// www3.telus.net/linguisticsissues/selfasess2.html.

Covington M. V. (2000). Goal theory, motivation, and school achievement: An integrative review. In ST Fiske, DL Schachter, C Zahn-Waxler (Eds.), Annual review of psychology, 51: 171-2000. Palo Alto, CA: Annual Reviews

Dickinson, L. (1987). Self-instruction in language Learning .Cambridge University Press.

Dornyei Z. (2000). Motivation' \& 'Motivation Theories. In M. Byram (Ed.) Routledge Encyclopedia of Language Teaching and Learning. London: Routledge, pp. 425-435.

Dornyei, Z. (2009). The L2 Motivational Self System. In Z. Dornyei \& E. Ushioda (Eds.) Motivation, Language Identity and the L2 Self. Clevedon: Multilingual Matters.

Erwin, T.D. (1991). Assessing Student Learning and Development, Jossey-Bass.

Harris ,M. (1997). Self-assessment of language learning in formal settings. ELT 51(1), 12-20.

Hotard, D. J. (2010). The effects of self-assessment on student learning of mathematics. The Interdepartmental Program in Natural Sciences. pp. 1-72

Jack C .Richards \& Richard Schmidt. (2002). Dictionary of language teaching \& applied linguistics, London: Pearson Education Limited.

Liang, J. (2006). Overview of Self-assessment in the Second Language Writing Classroom. Paper presented at the 2006 TESOL Convention, Tampa, Florida. Available: http://secondlanguage writing.com/documents/overview.doc.

Oscarson, M. (1989). Self-assessment of Language Proficiency: Rationale and Applications. Language Testing,6(1), $1-13$.

Mousavi, A. (1991). A dictionary of language testing (2 ${ }^{\text {nd }}$ ed.). Tehran: Rahnama Publication

Naeini, J. (2011). Self-assessment and the impact on language skills. Educational Research, 2(6), 1225-1231.

Nakanishi, T. (2002). Critical Literature Review on Motivation. Journal of Language and Linguistics. Vol. 1(3) pp. 278-290.

Noonan, B. (2000). Demystifying Assessment Leadership. Educational Administration, University of Saskatchewan. 2(3). pp.1-20

Rahman, F., Jumani, N., \& Basit, A. (2010). Motivating and de-motivation factors among learners. International Journal of Academic Research. 2(1), p.206-212

Tamjidi, N . \& Birjandi, P. (2010) . The Role self-assessment in Promoting Iranian EFL learner's Motivation .English Language Teaching, Vol. 3, No. 3; September 2010.

Wang, H., \& Wang, Y. (2007) . The Addition of an Affect Test and Self-assessment into ESL Writing Assessment: Process and Effect. Asian EFL Journal,20. 